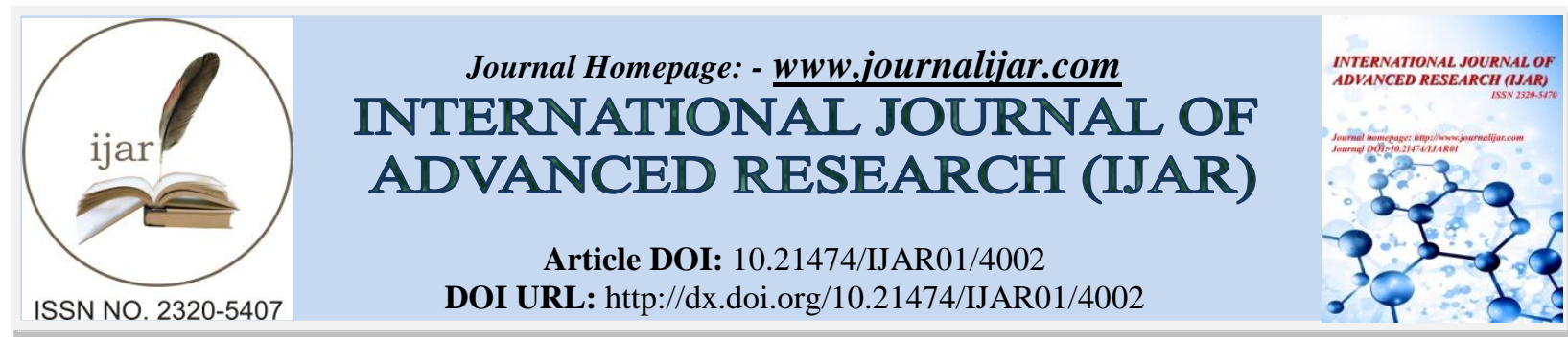

RESEARCH ARTICLE

\title{
ASSESSMENT OF LIPASE ENZYME AND CO FACTOR CHLORIDE IN SUDANESE DIABETIC PATIENTS TYPE 2.
}

\author{
Nagat Ali Elbeed ${ }^{1}$, Nuha Eljaili Abubaker ${ }^{2}$ and Ali Elamin Nasir ${ }^{3-}$ \\ 1. Elneelin University, college of medical laboratory science. \\ 2. Sudan university of science and Technology, colleges of medical laboratory science.(Head department of \\ clinical chemistry). \\ 3. Sudan university of science and Technology, colleges of medical laboratory science.
}

\section{Manuscript Info}

[.........................

Manuscript History

Received: 13 February 2017

Final Accepted: 05 March 2017

Published: April 2017

\section{Abstract}

Diabetes Miletus is characterized by hyperglycemia and there are many chemicals changes in this disease increase or decrease such as lipase and chloride which increase in type two diabetic patients.

This study was carried out to measure serum level of lipase and chloride in diabetic patients type two. Fifty blood samples were collected from patients in period between Junes to October 2016, chosen from Alribat hospital and fifty normal individuals as control.

Serum lipase measured by using mindray 380 , while serum chloride measured by using iron selective electrode ( Easylyte) .

This study showed $62 \%$ of patients over forty four years and $58 \%$ were females.

The study showed that patients with type two diabetes mellitus had significantly higher in means serum lipase and chloride compared to control group ( $19.39+10.34)$ vs. $(14.71 \pm 8.26 \mathrm{Iu} / \mathrm{l})$ and $(110.37 \pm$ $6.42)$ vs . ( $102 \pm 27 \pm 2.30 \mathrm{mmol} / \mathrm{l})$ respectively.

There were significantly positive correlation between serum lipase, chloride in diabetic patients type two and duration of disease . $(\mathrm{r}=$ $0.322, \mathrm{p}$-value $=0.023)(\mathrm{r}=0.737, \mathrm{p}$ - value $=0.000)$ respectively.

There was insignificant weak positive correlation between serum lipase in diabetic patients type two and age . $(\mathrm{r}=0.130$, $\mathrm{p}$-value $=$ $0.366)$, there was negative correlation between serum chloride in diabetic patients type two and age $(r=-0.301$, $p$-value $=0.002)$.

It is concluded that; the levels of lipase and chloride are significantly increased in patients with type $2 \mathrm{DM}$, and there were positive correlation between the levels of this parameters and duration of disease.

Copy Right, IJAR, 2017,. All rights reserved.

\section{Introduction:-}

Diabetes Mellitus is a group of metabolic disease characterized by hyperglycemia resulting from defect in insulin secretion, insulin action or both and there are four categories' of diabetes which are type one D.M , type two D.M ,specific type of D.M and gestational D.M. ${ }^{(1)}$

Corresponding Author:- Nagat Ali Elbeed.

Address:- Elneelin University, college of medical laboratory science. 
Type two D.M is characterized by hyperglycemia as a result of an individual's resistance to insulin with an insulin secretary defect which result in a relative not absolute insulin deficiency, and it is constitute the majority of diabetes cases and most patients are obese. ${ }^{(2)}$

Lipase is an enzyme that hydrolyzes the ester linkage of fats to produce alcohols and fatty acid. It is found primarily in the pancreas although it is also present in the stomach and small intestine. The reference rang of it is $(<38 \mathrm{U} / \mathrm{L}$ $\left.\left.37^{\circ} \mathrm{C}\right),<0.6 \mathrm{M} \mathrm{kat} / \mathrm{L}\right){ }^{(3)}$

Chloride (CL-) is a major extra cellular anion, it is involved in maintaining osmolality, blood volume and electric Neutrality. In most processes $\mathrm{CL}-$ shift secondarily to movement of $\mathrm{Na}+$ or $\mathrm{HCO} 3-$. The reference rang is $98-100$ $\mathrm{mmol} / \mathrm{L}{ }^{(4)}$

The elevation of lipase enzyme due to inflammation of the pancreas. ${ }^{(5)}$ And elevation of serum CL- level might be due to diabetic ketoacidosis which cause reduction in blood $\mathrm{PH}$ which further disturbs acid base balance and lead to elevation of chloride. ${ }^{(6)}$

\section{Material and Method:-}

Study population: The study was carried out at Alribat hospital, and the subjects were recruited from Alribat hospital, in Khartoum from June to October 2016. A total of 100 individual's were enrolled in this study and divided into two groups, 50 healthy individual's (control group) and 50 patients with diabetic type two.

The study was approved by hospital's ethics committee. Informed consent was obtained from patients before blood sampling.

\section{Inclusion Criteria:-}

Any patients with diabetic type two agree to participate in study

\section{Exclusion criteria:-}

patients with pancreatitis cholecytites, kidney failure, intestinal ulcer, Celiac disease, diabetes insipidus, dehydration " due to vomiting diarrhea and high fever", any patients take medication that can effect the result such as (Furosemide, corticosteroid, oral contraceptives) and any patients refused to participate in the study were excluded.

\section{Blood sample and Analysis:-}

About $3 \mathrm{ml}$ of venous blood was collected from artecubital vein by taking aseptic precautions. Care was taken to prevent venous stasis during the sample collection. The blood was allowed to clot and the serum was separated by centrifugation. Stored in $-8 \mathrm{c}$. The estimation of the parameters was carried out within 7 days, The samples were analyzed for serum lipase by automation mindray $380^{(7)}$ and for serum chloride by electrolyte analyzer ( easylyte) . The internal control sera of two different levels were used to calibrate the instruments.

Data was analyzed using SPSS computer program, the mean and standard deviation were obtained and the independent 't.test' used for comparison ( $\mathrm{P}$ value of $\leq 0.05$ ) was conßidered significant. 


\section{Results:-}

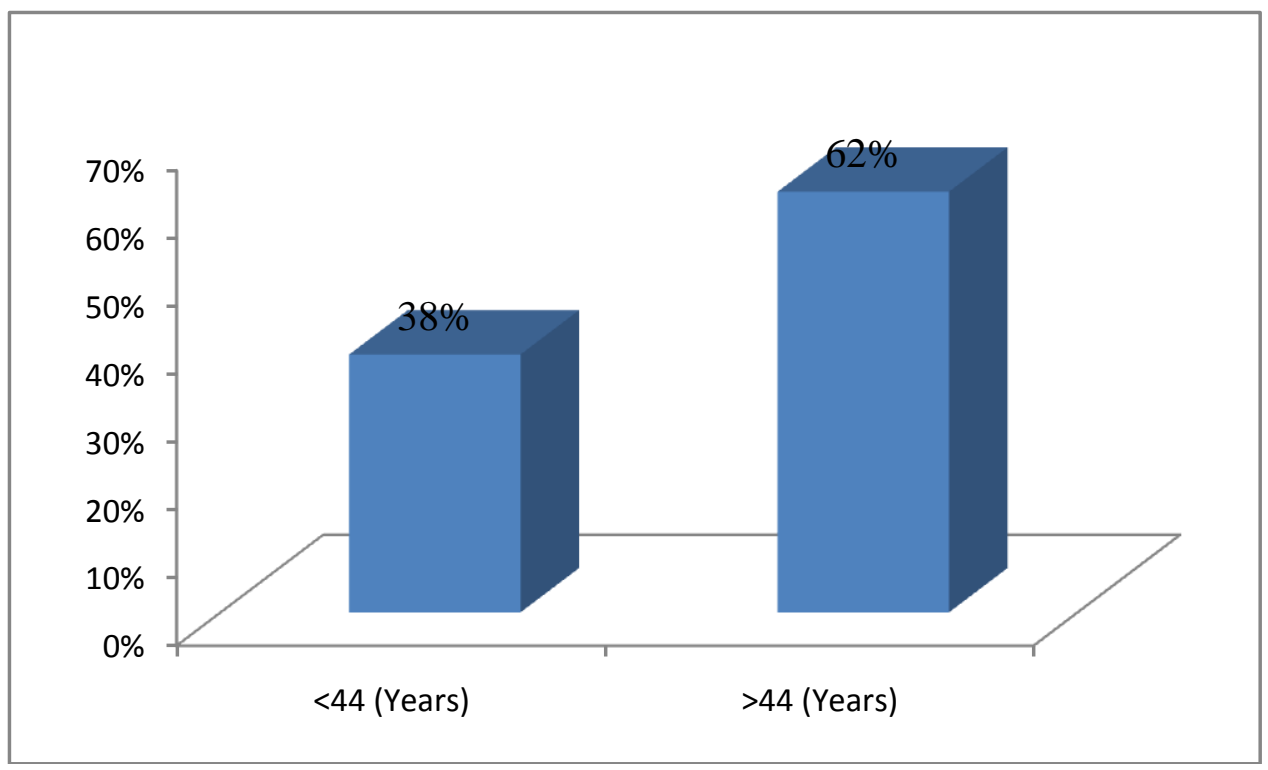

Figure 1:- distribution of patients according to age groups.

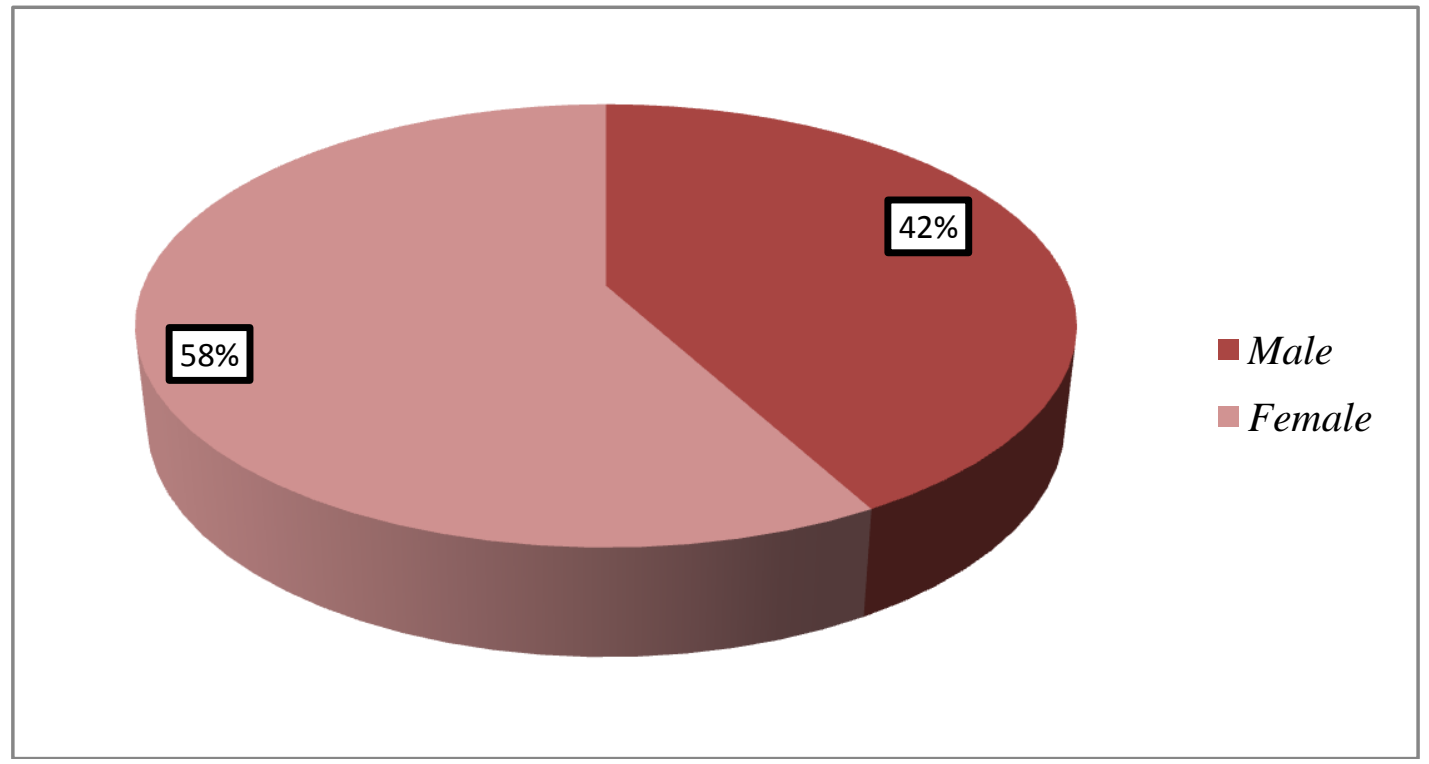

Figure 2:- frequency and percentage of male and female in patients group.

Table 1:- means comparisons of serum lipase and chloride in diabetic patients type 2 compared to control group.

\begin{tabular}{|l|l|l|l|}
\hline Variable & $\begin{array}{l}\text { Patients } \\
\text { N=50 } \\
\text { Mean } \pm \text { SD }\end{array}$ & $\begin{array}{l}\text { Control } \\
\text { N=50 } \\
\text { Mean } \pm \text { SD }\end{array}$ & P-value \\
& $19.39 \pm 10.34$ & $14.71 \pm 8.26$ & 0.000 \\
\hline Lipase (IU/L) & $110.37 \pm 6.42$ & $102.27 \pm 2.30$ & 0.000 \\
\hline Chloride $(\mathrm{mmol} / \mathrm{L})$ & &
\end{tabular}

Results given in mean \pm SD.

p-value $\leq 0.05$ consider significant. 


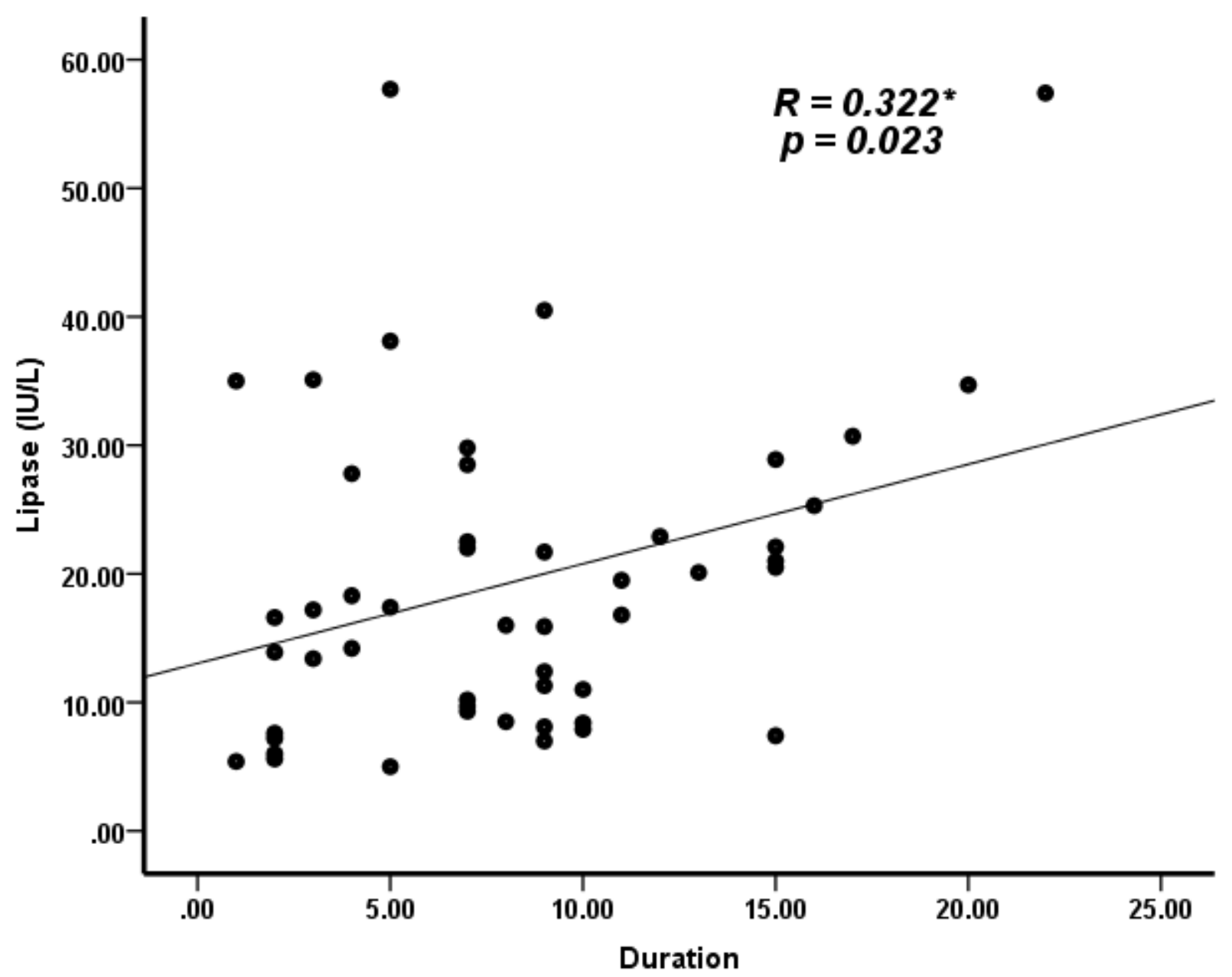

Figure 3:- correlation between lipase and duration of disease. $(r=0.322, p$. value $=0.023)$. 


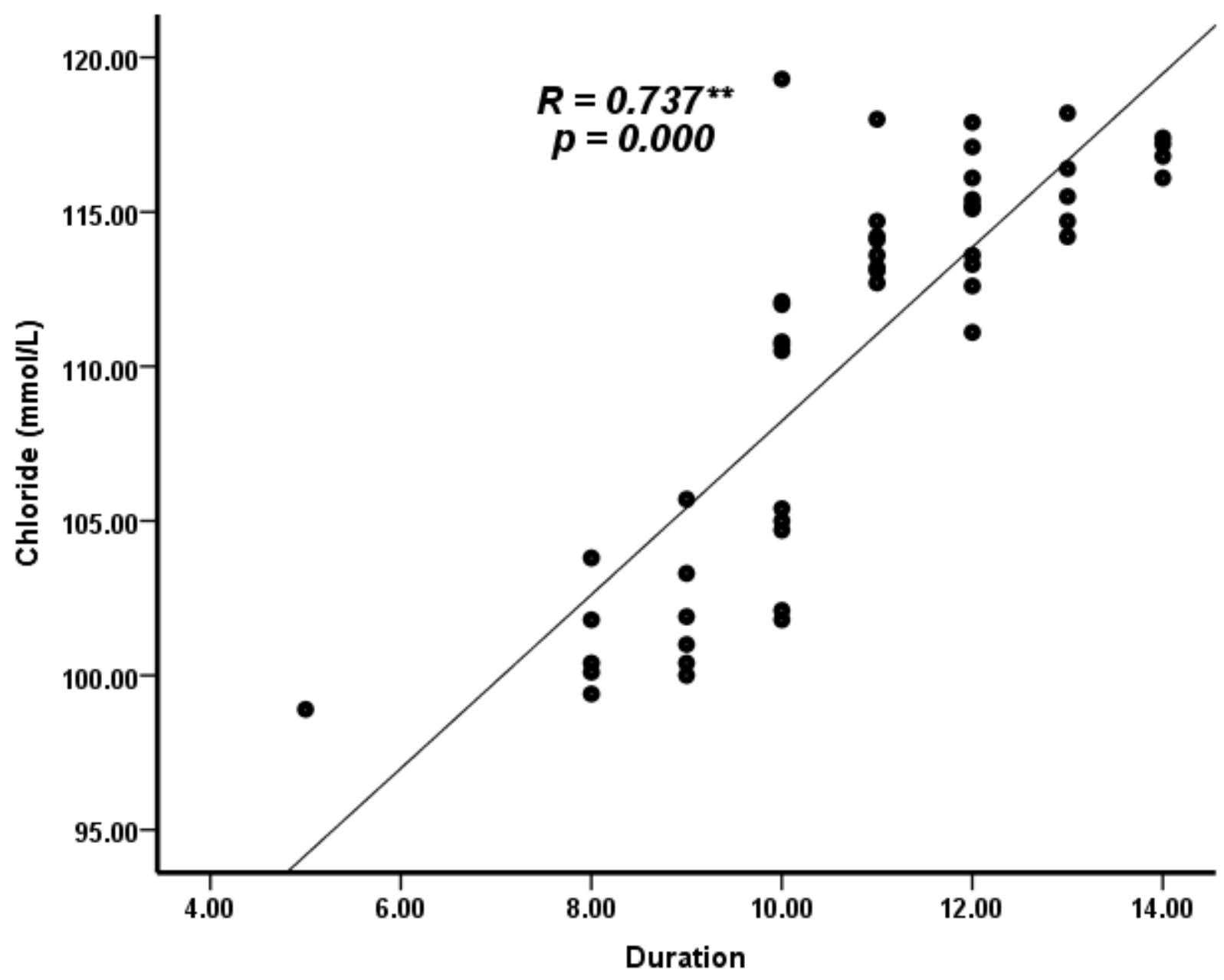

Figure 4:- correlation between chloride and duration of disease $(r=0.737, p$-value $=0.000)$. 


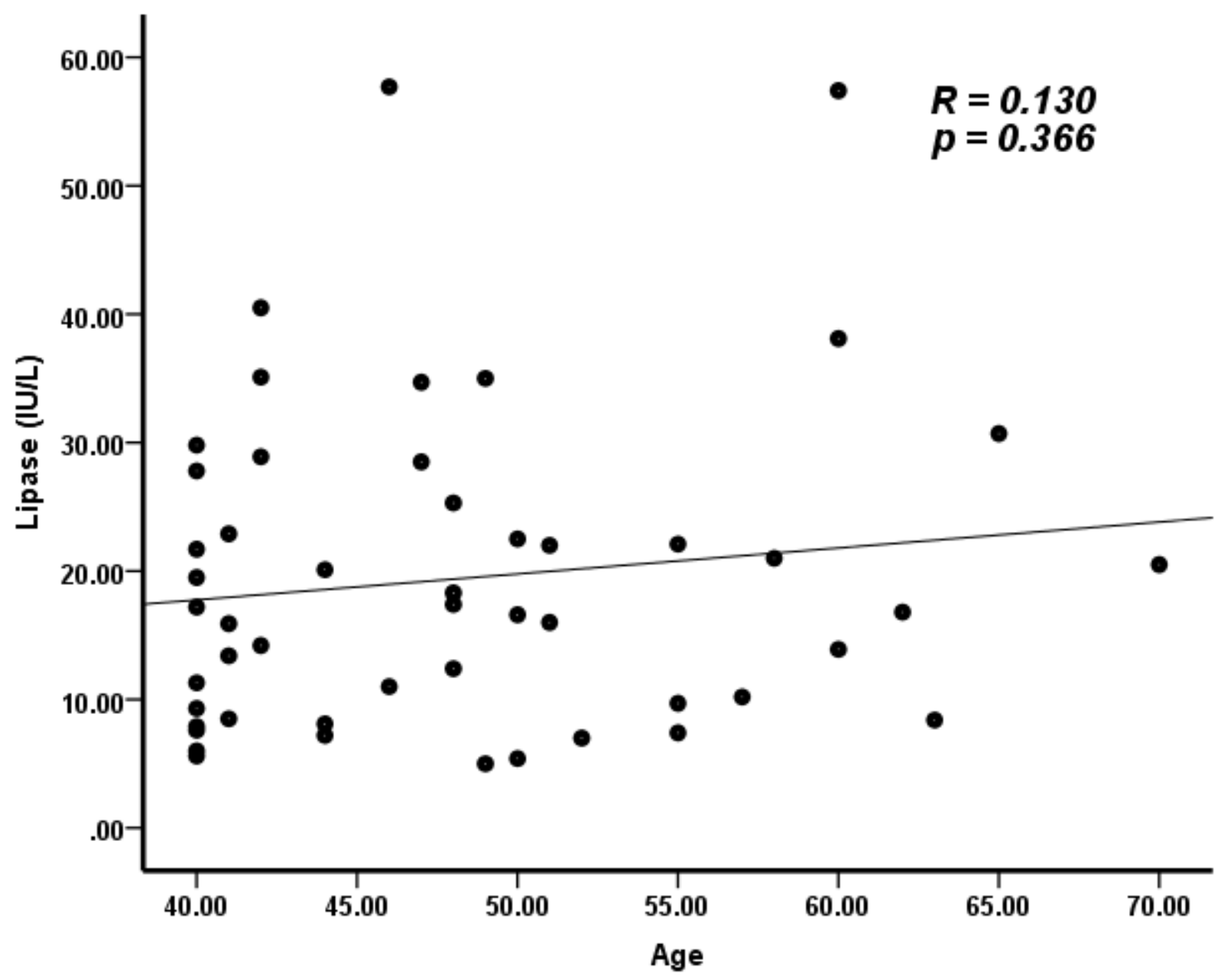

Figure 5:- correlation between lipase and age $(\mathrm{r}=0.130, \mathrm{p}$-value $=0.366)$. 


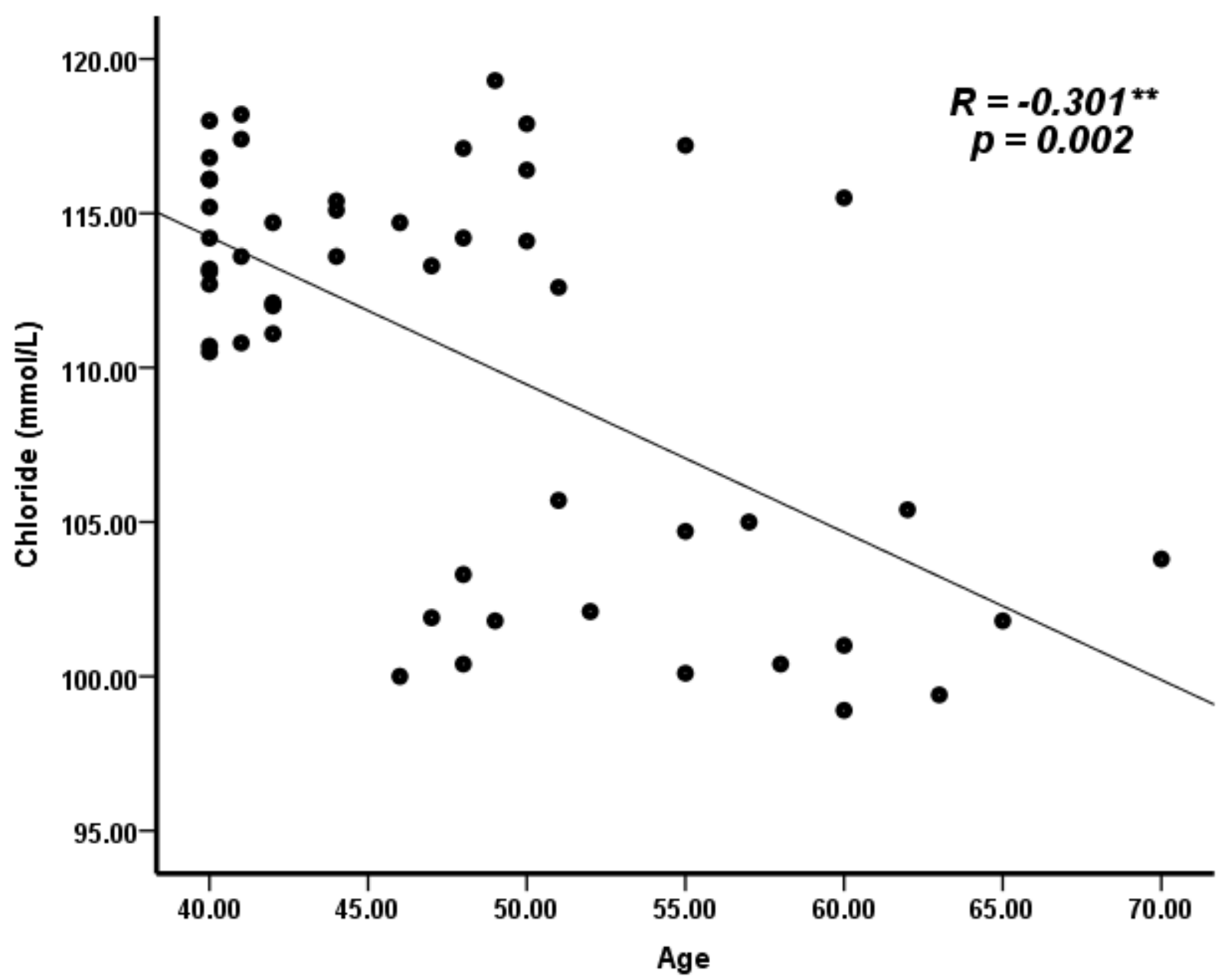

Figure 6:- correlation between chloride and age. $(\mathrm{r}=-0.301$, $\mathrm{p}$ - value $=0.002)$.

\section{Discussion:-}

The main patho physiological feature of type two diabetic patients are impaired insulin secretion and are impaired resistance $^{(8)}$, serum pancreatic enzyme levels may reflect the impaired exocrine- endocrine relationship in the pancreas. ${ }^{(9)}$

The finding obtained from specially designed questionnaire revealed that the majority of diabetic patients type 2 in this study were above 44 years (62\%). Sex distribution in type2 DM patients in this study revealed that $58 \%$ were females. This result agreed with the previous study, which found that, women were more likely to have DM, due to obesity and be less physically active. ${ }^{(10)}$

From the finding of this study it appears that serum level of lipase enzyme was significantly increased in diabetic patients group in compare to control group ( $\mathrm{p}$, value $=0.000$ ). This result agreed with a study carried by many authors ${ }^{(10,11)}$, which showed that; the high serum lipase activity in diabetes can interfere the pancreas exocrine endocrine interaction. Because of the insulin stimulates enzymes synthesis and release in the exocrine pancreas, the high activity of lipase in diabetes are associated with an impaired insulin action due to insulin resistance and in adequate insulin secretion .

Also the result in agreement with another result which found, the increasing activity of lipase in type 2 DM indicate pancreatic exocrine inflammation. ${ }^{(12)}$ 
Result in this study showed significant increased in serum chloride level in type 2 DM patients compared to control group $(\mathrm{p}$, value $=0.000)$.

This result similar to another result, which reported alterations of all electrolytes during insulin induced hypoglycemia in diabetic patients and causes increases in serum chloride level. ${ }^{(13)}$ Also this result is similar to another result which found:

The serum Cl- value in the diabetic group was significantly increased compared to control group, this elevation of chloride level due to diabetic ketoacidosis may be responsible for elevated chloride level in type 2 diabetes patient, keto acids reduce blood $\mathrm{pH}$ disturbing acid base balance and leads to elevation of chloride. ${ }^{(14)}$

Also this result in agreement with another result which showed that, electrolytes abnormalities are common in diabetic patients and may be associated with increased morbidity and mortality. Patients with DM may receive complex drug regimens some of which may be associated with electrolyte disorders. ${ }^{(15)}$

Also in this study as appeared in figures (3), there was weak positive correlation between serum lipase enzyme level and duration of disease. This result agree with another result which showed, the high value of serum lipase has positive correlation with the duration of Indonesian T2D, because uncontrolled glucose levels can stimulate level of triglyceride and it will stimulate the lipase secretion to degrade triglyceride into free fatty acid. ${ }^{(16)}$

In this study as appeared in figures (4), there was strong positive correlation between serum chloride level and duration of disease. This result in agreement with another result which found, on relationship between urinary excretion of the biochemical indices (include chloride) and duration of the diabetes further confirmed that the biochemical indices are not only altered but the alteration varies with the duration of the disease, the mechanism for the alteration of these urine biochemical indices in the diabetic subjects might be attributed to the development of kidney dysfunction ${ }^{(17)}$

There was insignificant weak positive correlation between the age of patients and lipase enzyme level and there was significant negative correlation between the age of patients and serum chloride level.

\section{References:-}

1. Shoback, D.G., Gardner,D., Greenspan's basic and clinical endocrinology.2011 (9th ed). Chapter 17.

2. American Diebetes Association . Diagnosis and classification of diabetes mellitus. Diabetes care.2014;37(1):581-590.

3. Svendsan A “Lipase protein Engineering” Biochim Biobhys . 2000; (2) : 223-228.

4. Michael, L., Bishop, M.S., Larry, E and Schoeff, M.S. Clinical Chemistry. 2013 seventh Edition Chapter 16.

5. Diabetes Association. Standers of medical care in diabetes. Diabetes care.2013: 36(1): 11-26.

6. Jamel , A.J "Estimation of serum electrolytes in diabetes patient of Saudi Regiion" Life Sci J. 2014; 11(7): 378380.

7. Power, A.C. Diabetes mellitus. In Braunald, E., Fauci, A.S., Kasper, D.L., Hauser, S.L., Longo, D.L., Jameson, J.L. editors. Harrison's Principles of Internal Medicine. 17th ed. New York. McGraw Hill: 2286.

8. Kohei , K. Pathophysiology of type 2 diabetes and its treatment policy. J Japan 2010; 53(1):41-46.

9. Arie, S., Djoko W. S., Fatchiyah ., Aulanni'am. Relation of Elevated Serum Lipase to Indonesian Type 2 Diabetes Mellitus Progression. Biomed Res- India 2015 ; 26(2) :293-298.

10. Karamatollah , R., Mohammad , S and Abdolreza, S. J . Relation of type 2 diabetes mellitus with gender, education, and marital status in an Iranian urban population. Rep Biochem Mol Biol 2013;1(2) :64-68.

11. Andren, A.K., Hardt, P.D. Workshop report: Giessen international workshop on interaction of exocrine and endocrine pancreatic disease. J pancreas 2005;6(4):382-405.

12. Beauregard, J.M., Lyon, J.A., Slovis, C. Using the literature to evaluate diagnostic test: amylase or lipase or diagnosis acute pancreatitis ?. JMed Lipr Assoc 2007;95(2):121-126.

13. Caduff, A., Lutz, H.U., Heinemann, L., Di Benedetto, G., Talary, M.S., Theander, S. Dynamics of blood electrolytes in repeated hyper- and/or hypoglycaemic events in patients with type 1 diabetes. Diabetologia. 2011;54:2678-2689.

14. Alaka Das and Saurabh Borkotoki. Evaluation of Serum Electrolyte Levels in Type 2 Diabetes Mellitus Indian Journal of Applied Research 2016; 6 ( 8) : 91-93 
15. Liamis ,G., Liberopoulos, E.,Barkas ,F and Elisaf , M. Diabetes mellitus and electrolyte disorders 2014;2(10):488-496.

16. A Srihardyastutie, D.W., Soeadmadji, F., Fatchiyah, A. Aulanniam. Lipase/amylase ratio as the indication of pancreatic exocrine inflammation and the correlation with insulin resistance in type 2 diabetes mellitus. Proceeding of the 4th Annual Basic Science International Conference (BASIC) Indian Journal of Applied Research 2014; 33(37): 91-93

17. Adeosun, O.G., Anetor, J.I., Jayeola, O., Ikem, T.R .,Kolawole,A.B., Fatiu, A., Arogundade and Samuel O. Evaluation of alterations in the urine biochemical profiles of type 2 diabetes mellitus patients in Southwest, Nigeria.

18. African Journal of Biotechnology 2014 ;13(1):175-180. 